\title{
SUBSTRATE GROUPS OF BRYOPHYTES IN THE TERRITORY OF THE ZNESINNYA REGIONAL LANDSCAPE PARK (LVIV, UKRAINE)
}

\author{
Zvenyslava MAMCHUR ${ }^{1}$, Yuriy DRACH ${ }^{1}$, Marina RAGULINA ${ }^{2}$, Sergii PRYTULA ${ }^{1}$, Halyna ANTONYAK ${ }^{1}$ \\ 1. Ivan Franko National University of Lviv, 4, Hrushevskyi St, UA-79005 Lviv, Ukraine \\ 2. State Museum of Natural History, National Academy of Sciences of Ukraine, Teatralna St. 18, \\ UA-290008 Lviv, Ukraine \\ e-mail: halyna.antonyak@Inu.edu.ua
}

\begin{abstract}
The article presents data on the diversity and substrate groups of bryoflora of the Znesinnya Regional Landscape Park (Znesinnya RLP), located in the city of Lviv (Western Ukraine). Based on field research carried out in the period 2015-2018 and analysis of herbarium collections, an inventory was made of the bryoflora of the Znesinnya RLP. A total of 113 species of bryoflora belonging to 66 genera, 35 families and 2 divisions are presented from the investigated area. Of these, 105 species are members of the division Bryophyta and 8 belong to Marchantiophyta. Six regionally rare species of bryophytes have been recorded, namely Pellia endiviifolia, $P$. epiphylla, Encalypta streptocarpa, Fissidens exilis, Cirriphyllum crassinervium and Sciurohypnum starkei. With regard to substrate preferences, epigeous species of bryophytes predominated and accounted for $89.0 \%$ of the total number of species. The largest proportion of bryophytes occurred on bare soil $(46.0 \%)$, while $36.3 \%$ and $25.7 \%$ species were found on soil among herbaceous vegetation and on soil with gravel, respectively. Stony substrates were colonized by $42.5 \%$ of bryophyte species, with $19.5 \%$ of species occurring on artificial stony substrates. In addition, $24.8 \%$ of the species belonged to epixils inhabiting old stumps and logs of varying degrees of decay, and the same proportion was represented by epiphytic species of bryophytes. The smallest proportion (10.7\%) of bryophytes was confined to water bodies and swampy ecotopes.
\end{abstract}

Keywords: bryophytes, substrate groups, urban parks, Lviv, Ukraine

\section{Introduction}

Expanding urbanization significantly alters natural habitats and negatively affects biodiversity, creating a risk of reduction of species distribution areas and extinction of vulnerable groups of biota. In this context, city parks, forest parks and gardens are intended not only to provide recreational opportunities for citizens, but also to protect natural diversity and ecological complexes in urban ecosystems. However, city parks, often surrounded by buildings and urban infrastructure, are constantly exposed to a variety of anthropogenic stress factors. Various types of recreational activities in parks and nature protected areas, as well as atmospheric pollution due to industrial and transport loads in the adjacent territories, adversely affect the species composition and metabolic activity of vegetation, including bryophytes inhabiting urban parks [11,30-31, 34$35,37-37,41]$. In particular, a comparison of data on bryophyte diversity in the parks of the city of Lviv (Western Ukraine) from the last century with current data indicates the disappearance of some species sensitive to air pollution and other factors associated with anthropogenic pressure [30-31]. On the other hand, city parks and protected landscape areas often include diverse ecotopes with a wide range of substrates, both natural and artificial, creating new ecological niches for 
bryophyte species.

Znesinnya Regional Landscape Park (Znesinnya RLP) was created in the territory of Lviv primarily to protect and preserve unique natural, historical and cultural complexes and objects, as well as for recreational, ecological, cultural, educational, and research activities. The park presents a variety of natural landscapes and refuges for nature, archeology and architecture; however, it also contains areas devastated by anthropogenic activity. Therefore, the territory of the Znesinnya RLP can be used as a model for studying the diversity of bryophytes in city parks and for assessing changes in bryophyte species richness that occur under the influence of anthropogenic pressure.

The bryological studies carried out in the Znesinnya RLP in recent years have been rather fragmentary, being mainly limited to research in certain areas of its territory (e.g., within the environs of an Open-Air Museum of Folk Architecture and Life) [21, 28-29, 39]. In addition, there are virtually no past data on the distribution of bryophytes in this area that could be compared with their current status.

The aim of the present study was to make an inventory of bryophyte species in the territory of Znesinnya RLP, to determine their substrate specificity, to survey the main ecotopes of the park in search of rare species, and to analyze the ecological characteristics of synanthropic species of bryoflora. This work is based on the results of field studies carried out during the period 20152018. The herbarium specimens of bryophytes collected from the territory by the authors in previous years, and literature data, were also analyzed.

\section{Materials and Methods}

\section{Study area}

The city of Lviv is located in the western part of Ukraine $\left(49^{\circ} 83^{\prime}-49^{\circ} 50^{\prime} \mathrm{N}\right.$ and $24^{\circ} 00$ $24^{\circ} 10^{\prime}$ E, 320-382 $\mathrm{m}$ asl) and covers an area of $182 \mathrm{~km}^{2}$ with approximately 730,270 inhabitants. Znesinnya Regional Landscape Park with a total area of 785.71 ha is located in the north-eastern part of Lviv and has a length of $3.3 \mathrm{~km}$ from west to east and $1.4 \mathrm{~km}$ from north to south. Znesinnya RLP was established in 1993 and at that time it became the first landscape park in Ukraine to be created on the territory of a large industrial city. Its original area was 312.1 ha, but subsequently a protective zone of 473.61 ha was allocated to regulate the impact of the urban environment and to form a single natural-architectural ensemble of the park and neighbouring territories. At present, the main goal of the Znesinnya RLP as an object of the Nature Reserve Fund of Ukraine is the preservation of the unique geological and floristic complexes of the Znesinnya Ridge, as well as the protection of archaeological and historical sites.

Znesinnya RLP covers the natural landscapes of the wooded hills of the Lviv Plateau, the territory of Klymentiy Sheptytsky Open-Air Museum of Folk Architecture and Life (known as Shevchenkivskyi Grove, or Lviv Skansen), and many valuable complexes and items of nature, history and culture. Consequently, in addition to the natural area, it contains historical and cultural zones (places of historical battles, locations of cultural, educational and national centres, churches, monasteries, and a cemetery of the mid-19th century). A part of the territory in its protective zone is occupied by low-rise residential buildings with personal plots, historic medium-rise buildings, educational and medical institutions, several industrial, sports and military facilities, engineering structures and transport network (Fig. 1).

Until the 1990s, part of the park was intensively transformed because of the opencast development of sand reserves; as a result, quarries and technologically altered territories occupy 
about one quarter of the park's area. Old quarry workings, which were exploited in the 19th century and earlier, are common on the higher levels of the relief with absolute elevations of 330-345 m. On the lower levels of the relief, there are inactive quarries of the post-war period (late 20th century).

A feature of the Znesinnya RLP is its proximity to the central part of the city, which is why the park is surrounded on all sides by buildings and city streets, and active transport roads with public transport stops pass through a protected area. The close location to the city center leads to an increased recreational load on the park area.
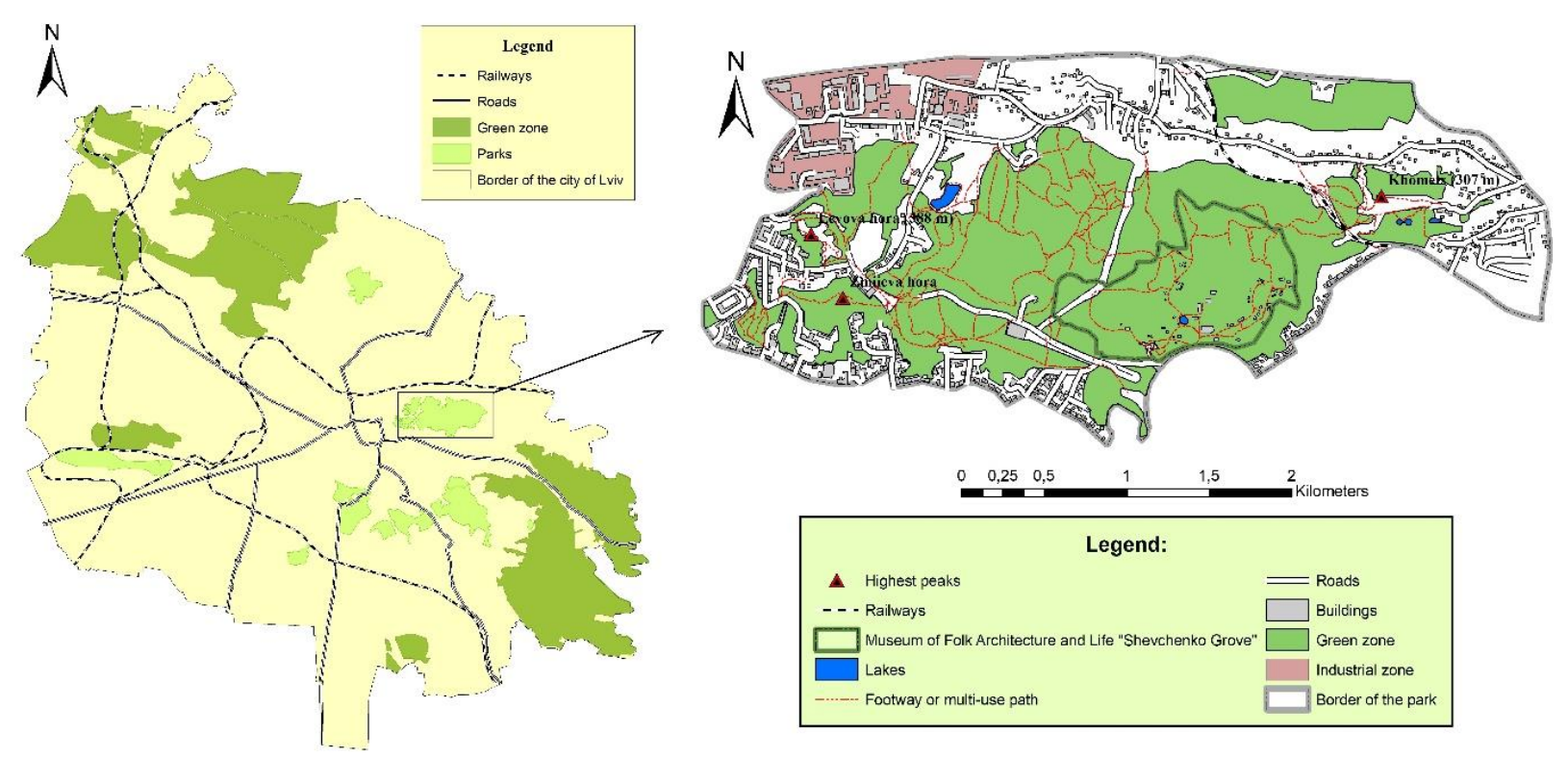

Fig. 1: Location map of the Znesinnya Regional Landscape Park $\left(49^{\circ} 50^{\prime} 47^{\prime \prime} \mathrm{N} 24^{\circ} 03^{\prime} 41^{\prime \prime} \mathrm{E}\right)$ in the city of Lviv

\section{Collecting and analysis of plant material}

Field studies were carried out using the traditional route method during the growing seasons of 2015-2018. Within the territory of Znesinnya RLP, various ecotopes were surveyed: forested area, open areas with herbaceous vegetation, water bodies and their banks, devastated areas (destroyed by quarries, dumps, as well as by paths and roads), and historic cultural sites. The material was collected using standard methods; descriptions of the collected samples included detailed substrate characteristics, GPS coordinates, and collection dates. Bryophyte species were identified in the laboratory by morphological and anatomical features using keys and descriptions from various literature sources [2-5, 10, 18-19, 42]. The bryophyte taxa names were used according to Hodgetts et al., 2020 [17]. The frequency of occurrence was estimated in the range from 1 to 3: 1 - singly, 2 - sporadically, and 3 - often occurring species (common species). Based on the study carried out by Boiko, 2010 [6], regionally rare bryophytes were noted for the Znesinnya RLP. The collected specimens were housed in the herbaria of the Department of Ecology of Ivan Franko National University of Lviv and the State Museum of Natural History of the National Academy of Sciences of Ukraine (LWKS). 


\section{Results}

Research carried out on the territory of Znesinnya RLP made it possible to identify 113 species of bryophytes (of which 8 species were in the division Marchantiophyta) belonging to 35 families and 66 genera. Of the eight families of liverworts, two families (Marchantiaceae and Pelliaceae) each include 2 species of the same genus. Other families (Blasiaceae, Cephaloziaceae, Conocephalaceae, Radulaceae) include one genus and one species each (Fig. 2).

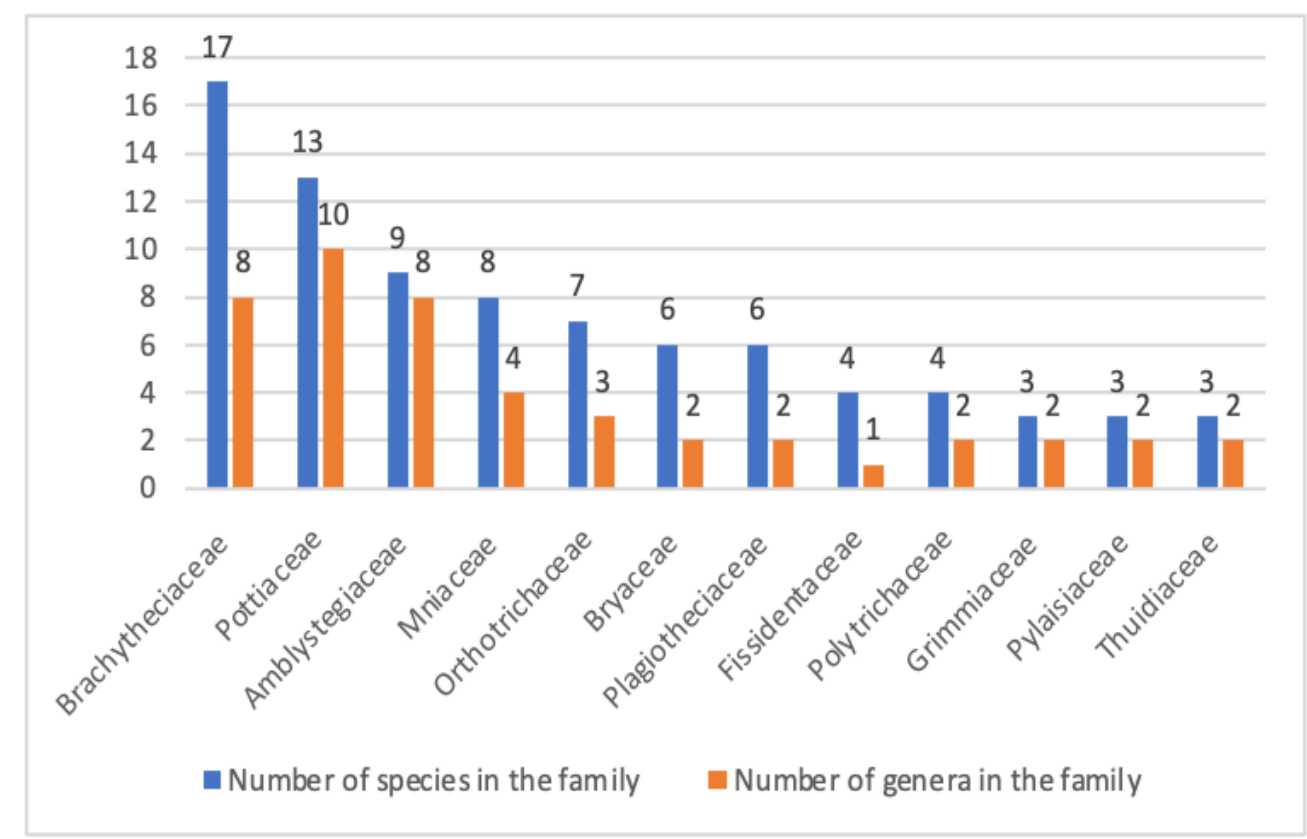

Fig. 2: The number of species and genera in the dominant families of bryophytes in the territory of Znesinnya RLP

Five families in the division Bryophyta (Dicranaceae, Dicranellaceae, Encalyptaceae, Ditrichaceae, Hylocomiaceae) are represented by 2 species each, and 12 families in this division (Calliergonaceae, Climaciaceae, Funariaceae, Hypnaceae, Jocheniaceae, Lembophyllaceae, Leskeaceae, Myuriaceae, Neckeraceae, Pseudoleskeellaceae, Pylaisiadelphaceae) are represented by one genus and one species each (Table).

The distribution of the leading families in the floristic spectrum reflects the specificity of the local conditions of the Znesinnya RLP: the premier position of the families Pottiaceae, Bryaceae, and Orthotricaceae is characteristic of arid zones, but the high position of the family Amblystegiaceae is peculiar to the zone of deciduous forests.

With regard to substrate preferences, the largest number of bryophyte species occurred on soil, namely 101 species $(89.4 \%)$. In particular, 52 species $(46.0 \%)$ were found on bare soil, while $41(36.3 \%)$ and $29(25.7 \%)$ species were found respectively on soil among grass and on soil with gravel (Fig. 3). On stony substrates, 48 (42.5\%) species of bryophytes were found, with 22 species $(19.5 \%)$ occurring on artificial stony substrates. 
Table 1: Distribution and frequency of bryophyte occurrence on different types of substrates in the Znesinnya RLP

\begin{tabular}{|c|c|c|c|c|c|c|c|c|c|c|}
\hline \multirow[b]{2}{*}{ Species } & \multicolumn{10}{|c|}{ Type of substrate* } \\
\hline & $\mathbf{S t}$ & StA & SG & SO & SV & WR & $\mathbf{W L}$ & $\mathbf{W S}$ & PS & $\mathbf{A M}$ \\
\hline \multicolumn{11}{|c|}{ Marchantiophyta } \\
\hline Blasia pusilla L. & & & & 1 & & & & & & \\
\hline Cephalozia bicuspidata (L.) Dumort. & & 1 & & & & 1 & & & & \\
\hline Marchantia polymorpha L. & 3 & 2 & & 3 & & & & & & \\
\hline Marchantia quadrata Scop. & & & & 1 & & & & & & \\
\hline $\begin{array}{l}\text { Pellia endiviifolia (Dicks.) Nebel \& } \\
\text { D.Quandt }\end{array}$ & & & & & & & & & & 1 \\
\hline Pellia epiphylla (L.) Corda & & & & 1 & & & & & & 1 \\
\hline Radula complanata (L.) Dumort. & & & & & & & 1 & & & \\
\hline Conocephalum conicum (L.) Dumort. & & & & 1 & & & & & & 1 \\
\hline \multicolumn{11}{|c|}{ Bryophyta } \\
\hline Abietinella abietina (Hedw.) Fleisch. & & & & 1 & 1 & & & & & \\
\hline Aloina rigida (Hedw.) Limpr. & & & 1 & & & & & & & \\
\hline Amblystegium serpens (Hedw.) Schimp. & 2 & 2 & 1 & 2 & 1 & 2 & 3 & 3 & 1 & \\
\hline Atrichum undulatum (Hedw.) P.Beauv. & & & & 2 & 1 & 1 & & 2 & & \\
\hline Barbula unguiculata Hedw. & 1 & 1 & 2 & 2 & & & & & & \\
\hline $\begin{array}{l}\text { Brachytheciastrum velutinum (Hedw.) } \\
\text { Ignatov et Huttunen }\end{array}$ & & 1 & & 2 & & 2 & 3 & 1 & & \\
\hline $\begin{array}{l}\text { Brachythecium albicans (Hedw.) } \\
\text { Schimp. }\end{array}$ & & & 1 & 1 & 1 & & & & & \\
\hline $\begin{array}{l}\text { Brachythecium campestre (Müll.Hal.) } \\
\text { Schimp. }\end{array}$ & & & & & 2 & 1 & 1 & & & \\
\hline $\begin{array}{l}\text { Brachythecium glareosum (Bruch ex } \\
\text { Spruce) Schimp. }\end{array}$ & 2 & & 2 & & 2 & 2 & 1 & & & \\
\hline Brachythecium rivulare Schimp. & & & & & & & & & & 1 \\
\hline $\begin{array}{l}\text { Brachythecium rutabulum (Hedw.) } \\
\text { Schimp. }\end{array}$ & 2 & 1 & 2 & 3 & 3 & 3 & 1 & 1 & & 1 \\
\hline $\begin{array}{l}\text { Brachythecium salebrosum (Hoffm. ex } \\
\text { F.Weber \& D.Mohr) Schimp. }\end{array}$ & 2 & 1 & & 2 & 2 & 3 & 1 & 1 & & \\
\hline $\begin{array}{l}\text { Bryoerythrophyllum recurvirostrum } \\
\text { (Hedw.) P.C. Chen }\end{array}$ & 1 & & & & & & & & & \\
\hline Bryum argenteum Hedw. & 3 & 3 & 3 & 2 & 2 & & & & & \\
\hline Bryum klinggraeffii Schimp. & & & & 1 & & & & & & \\
\hline $\begin{array}{l}\text { Calliergonella cuspidata (Hedw.) } \\
\text { Loeske }\end{array}$ & 2 & & & & 2 & & & & 1 & 1 \\
\hline $\begin{array}{l}\text { Calliergonella lindbergii (Mitt.) } \\
\text { Hedenas }\end{array}$ & & & & & 1 & & & & & \\
\hline $\begin{array}{l}\text { Campyliadelphus chrysophyllus (Brid.) } \\
\text { R.S. Chopra }\end{array}$ & 1 & & 2 & 1 & 1 & & & & & \\
\hline $\begin{array}{l}\text { Campylophyllopsis sommerfeltii } \\
\text { (Myrin) Ochyra }\end{array}$ & & & & & & 1 & & & & \\
\hline Ceratodon purpureus (Hedw.) Brid. & 3 & 3 & 3 & 3 & 1 & 1 & & & & \\
\hline $\begin{array}{l}\text { Cirrhiphyllum crassinervium (Taylor) } \\
\text { Loeske \& M. Fleisch. }\end{array}$ & 1 & & & & & & & & & \\
\hline $\begin{array}{l}\text { Climacium dendroides (Hedw.) F.Weber } \\
\text { \& D.Mohr }\end{array}$ & & & & 1 & 1 & & & & & \\
\hline
\end{tabular}




\begin{tabular}{|c|c|c|c|c|c|c|c|c|c|c|}
\hline Cratoneuron filicinum (Hedw.) Spruce & & & 1 & 1 & 1 & & & & & 1 \\
\hline Ctenidium molluscum (Hedw.) Mitt. & 1 & & 1 & 1 & & 1 & & & & \\
\hline $\begin{array}{l}\text { Dicranella heteromalla (Hedw.) } \\
\text { Schimp. }\end{array}$ & & & & 2 & 1 & 1 & & 1 & & \\
\hline Dicranella varia (Hedw.) Schimp. & & & & 2 & & & & & & \\
\hline Dicranum montanum Hedw. & & & & & & & 1 & 1 & & \\
\hline Dicranum scoparium Hedw. & & & & 1 & & & 1 & & & \\
\hline Didymodon rigidulus Hedw. & 2 & & 1 & & & & & & & \\
\hline Didymodon vinealis (Brid.) R.H.Zander & 1 & & 1 & & & & & & & \\
\hline $\begin{array}{l}\text { Drepanocladus aduncus (Hedw.) } \\
\text { Warnst. }\end{array}$ & 2 & 1 & 1 & 2 & 1 & & & & 1 & 1 \\
\hline $\begin{array}{l}\text { Drepanocladus polygamus (Schimp.) } \\
\text { Hedenäs }\end{array}$ & & & & 1 & & 1 & & & & \\
\hline Encalypta streptocarpa $\mathrm{Hedw}$. & 2 & & 2 & 1 & & & & & & \\
\hline $\begin{array}{l}\text { Eurhynchium angustirete (Broth.) } \\
\text { T.J.Kop. }\end{array}$ & & & & 1 & 1 & & & & & \\
\hline Eurhynchium striatum (Hedw.) Schimp. & & & & & 1 & & & & & \\
\hline Fissidens adianthoides Hedw. & & & & 1 & & & & & & \\
\hline Fissidens dubius P.Beauv. & & & & 1 & & & & & & 1 \\
\hline Fissidens exilis Hedw. & & & & & 1 & & & & & \\
\hline Fissidens taxifolius Hedw. & & & 2 & 2 & 1 & & & & & 1 \\
\hline Funaria hygrometrica Hedw. & & & 2 & 2 & 1 & & & & & \\
\hline Grimmia pulvinata (Hedw.) Sm. & 2 & 2 & & & & & & & & \\
\hline Herzogiella seligeri (Brid.) Z.Iwats. & & & & & & 1 & & & & \\
\hline Homalia trichomanoides (Hedw.) Brid. & & & & & & & 1 & & & \\
\hline Homalothecium lutescens (Hedw.) H.Rob & & & 1 & 1 & & & & & & \\
\hline $\begin{array}{l}\text { Homalothecium sericeum (Hedw.) } \\
\text { Schimp. }\end{array}$ & 1 & & & & 1 & & & & & \\
\hline $\begin{array}{l}\text { Homalothecium phillipeanum (Spruce) } \\
\text { Schimp. }\end{array}$ & 1 & & & & 1 & & & & & \\
\hline $\begin{array}{l}\text { Hygroamblystegium varium (Hedw.) } \\
\text { Mönk. }\end{array}$ & 3 & 2 & & 3 & & 2 & 1 & & & \\
\hline $\begin{array}{l}\text { Hylocomiadelphus triquetrus (Hedw.) } \\
\text { Ochyra \& Stebel }\end{array}$ & & & & 1 & 1 & & & & & \\
\hline Hypnum cupressiforme Hedw. & 2 & 2 & & & & 2 & 3 & & & \\
\hline $\begin{array}{l}\text { Isothecium alopecuroides (Lam. ex } \\
\text { Dubois) Isov. }\end{array}$ & 1 & & & & & & 2 & & & \\
\hline $\begin{array}{l}\text { Jochenia pallescens (Hedw.) Hedenäs, } \\
\text { Schlesak \& }\end{array}$ & & & & & & & 1 & 1 & & \\
\hline Leptodictyum riparium (Hedw.) Warnst. & & & & & & & & & 1 & 2 \\
\hline Leskea polycarpa Hedw. & 1 & & & & & 3 & 3 & 1 & & \\
\hline $\begin{array}{l}\text { Lewinskya affinis (Schrad. ex Brid.) } \\
\text { F.Lara, Garilleti \&Goffinet }\end{array}$ & & & & & & 1 & 2 & & & \\
\hline $\begin{array}{l}\text { Lewinskya speciosa (Nees) F.Lara, } \\
\text { Garilleti \& Goffinet Nees }\end{array}$ & & & & & & & 2 & & & \\
\hline $\begin{array}{l}\text { Lewinskya striata (Hedw.) F.Lara, } \\
\text { Garilleti \& Goffinet }\end{array}$ & & & & & & & 1 & & & \\
\hline Mnium marginatum (Dicks.) P.Beauv. & 1 & & & & & & & & & \\
\hline Mnium stellare Hedw. & 1 & & & 1 & & & & & & \\
\hline
\end{tabular}




\begin{tabular}{|c|c|c|c|c|c|c|c|c|c|}
\hline $\begin{array}{l}\text { Nyholmiella obtusifolia (Brid.) Holmen } \\
\& \text { E.Warncke }\end{array}$ & & & & & & 2 & 2 & & \\
\hline Orthotrichum diaphanum Brid. & 1 & & & & & 1 & 1 & & \\
\hline Orthotrichum pallens Bruch ex Brid. & & & & & & & 2 & & \\
\hline Orthotrichum pumilum Sw. ex anon. & & & & & & & 3 & 1 & \\
\hline Oxyrrhynchium hians (Hedw.) Loeske & 2 & & 2 & 2 & 3 & 1 & & & \\
\hline Palustriella commutata (Hedw.) Ochyra & & & & & & & & & 1 \\
\hline $\begin{array}{l}\text { Plagiomnium cuspidatum (Hedw.) T. } \\
\text { Kop. }\end{array}$ & & & 1 & 2 & 2 & & & 1 & \\
\hline $\begin{array}{l}\text { Plagiomnium elatum (Bruch \& } \\
\text { Schimp.) T.J.Kop. }\end{array}$ & & & & 1 & & & & & \\
\hline $\begin{array}{l}\text { Plagiomnium rostratum (Schrad.) } \\
\text { T.J.Kop }\end{array}$ & 2 & & 2 & 3 & 2 & & & & \\
\hline $\begin{array}{l}\text { Plagiomnium undulatum (Hedw.) } \\
\text { T.J.Kop. }\end{array}$ & & & & 2 & 1 & & & 1 & \\
\hline $\begin{array}{l}\text { Plagiothecium cavifolium (Brid.) } \\
\text { Z.Iwats. }\end{array}$ & & & & & 1 & & & 1 & \\
\hline $\begin{array}{l}\text { Plagiothecium curvifolium Schlieph. ex } \\
\text { Limpr. }\end{array}$ & & & & & & & & 1 & \\
\hline $\begin{array}{l}\text { Plagiothecium denticulatum (Hedw.) } \\
\text { Schimp. }\end{array}$ & & & & & & 1 & & & \\
\hline Plagiothecium laetum Schimp. & & & & 1 & & 1 & & & \\
\hline Plagiothecium succulentum (Wils.) Lindb & & & & 1 & & & & & \\
\hline Platygyrium repens (Brid.) Schimp. & & & & & & 3 & 3 & 1 & \\
\hline Pleuridium subulatum (Hedw.) Rabenh. & & & & 1 & & & & & \\
\hline Pohlia nutans (Hedw.) Lindb. & & & 1 & 2 & 1 & & & & \\
\hline Polytrichum formosum Hedw. & & & & 1 & & & & & \\
\hline Polytrichum juniperinum Hedw. & & & & 1 & & & & & \\
\hline Polytrichum longisetum Sw. ex Brid. & & & & & 1 & & & & \\
\hline $\begin{array}{l}\text { Pseudoleskeella nervosa (Brid.) } \\
\text { Nyholm }\end{array}$ & 1 & & & & & & & 1 & \\
\hline $\begin{array}{l}\text { Pseudoscleropodium purum (Hedw.) } \\
\text { M.Fleisch. }\end{array}$ & & & & & 2 & & & & \\
\hline $\begin{array}{l}\text { Ptychostomum capillare (Hedw.) } \\
\text { Holyoak \& N.Pedersen }\end{array}$ & 3 & 2 & 3 & 1 & & & & 1 & \\
\hline $\begin{array}{l}\text { Ptychostomum imbricatulum } \\
\text { (Müll.Hal.) Holyoak \& N.Pedersen }\end{array}$ & 1 & 1 & 2 & 2 & & & & & \\
\hline $\begin{array}{l}\text { Ptychostomum moravicum (Podp.) Ros } \\
\text { et Mazimpaka }\end{array}$ & 1 & & & & 1 & & 3 & 2 & \\
\hline $\begin{array}{l}\text { Ptychostomum pseudotriquetrum } \\
\text { (Hedw.) J.R.Spence \& H.P. Ramsay ex } \\
\text { Holyoak \& N.Pedersen }\end{array}$ & 1 & 1 & & & & & & & \\
\hline Pylaisia polyantha (Hedw.) Schimp. & 2 & & & & & 2 & 3 & 3 & \\
\hline $\begin{array}{l}\text { Rhizomnium punctatum (Hedw.) } \\
\text { T.J.Kop. }\end{array}$ & 1 & & & & 2 & 1 & & & \\
\hline $\begin{array}{l}\text { Rhynchostegium murale (Hedw.) } \\
\text { Schimp. }\end{array}$ & 2 & 2 & 1 & & & & & & \\
\hline $\begin{array}{l}\text { Rhytidiadelphus squarrosus (Hedw.) } \\
\text { Warnst. }\end{array}$ & & & & 1 & 1 & & & & \\
\hline $\begin{array}{l}\text { Schistidium apocarpum (Hedw.) Bruch } \\
\text { et Schimp. }\end{array}$ & 1 & 3 & 2 & & & & & & \\
\hline
\end{tabular}




\begin{tabular}{l|l|l|l|l|l|l|l|l|l|l}
\hline Schistidium crassipilum H.H.Blom & 1 & 1 & & & & & & & & \\
\hline $\begin{array}{l}\text { Sciurohypnum populeum (Hedw.) } \\
\text { Ignatov \& Huttunen }\end{array}$ & & & & & & & 1 & 1 & & \\
\hline $\begin{array}{l}\text { Sciuro-hypnum starkei (Brid.) Ignatov } \\
\text { \& Huttunen }\end{array}$ & & & & & & 1 & & & & \\
\hline $\begin{array}{l}\text { Streblotrichum convolutum (Hedw.) } \\
\text { P.Beauv. }\end{array}$ & & & 2 & 1 & & & & & & \\
\hline Syntrichia papillosa (Wilson) Jur. & & & & & & 1 & 1 & & & \\
\hline $\begin{array}{l}\text { Syntrichia ruralis (Hedw.) F.Weber \& } \\
\text { D.Mohr }\end{array}$ & 1 & 1 & & 1 & & & 1 & 2 & & \\
\hline Thuidium assimile (Mitt.) A.Jaeger & & & & & 1 & & & & & \\
\hline Thuidium delicatulum (Hedw.) Schimp. & 1 & & & & 1 & & & & & \\
\hline Tortella tortuosa (Hedw.) Limpr. & 1 & & & & & & & & & \\
\hline Tortula muralis Hedw. & 3 & 3 & 1 & & & & & & & \\
\hline Tortula subulata Hedw. & 3 & 3 & 2 & 2 & & & & 1 & & \\
\hline Warnstorfia fluitans (Hedw.) Loeske & & & & & & & & & 1 & \\
\hline Weissia brachycarpa (Nees et & & & & & 1 & & & & & \\
Hornsch.) Jur. & & & & & 1 & & & & & \\
\hline Weissia longifolia Mitt. & & & & & & & & & & \\
\hline
\end{tabular}

* Substrates: St - stony substrates, rocks; StA - artificial stone; SG - soil with gravel or sand; SO - soil outcrops; SV - soil among herbaceous vegetation or leaf litter; WR - rotten wood; WL - living wood; WS - bark of protruding roots and base of trunks; PS - peat, swamp; AM - semi-aquatic or amphibious species

Note: The frequency of occurrence is indicated in the range from 1 to 3 , namely 1 - single occurrence, 2 - sporadic occurrence, 3 - frequent occurrence (common species)

Despite the insignificant amount of dead wood in the park, the survey of old stumps and fallen logs at different stages of decomposition made it possible to identify 28 species of epixilic representatives of Marchantiophyta and Bryophyta. There were 28 epiphytic species of bryophytes (24.8\%), and the same number of species was found on the lower part of tree trunks adjacent to the roots. The smallest groups of bryophytes in the park were represented by amphibious species and species common in boggy ecotopes, namely $9(8.0 \%)$ and $3(2.7 \%)$ species, respectively.

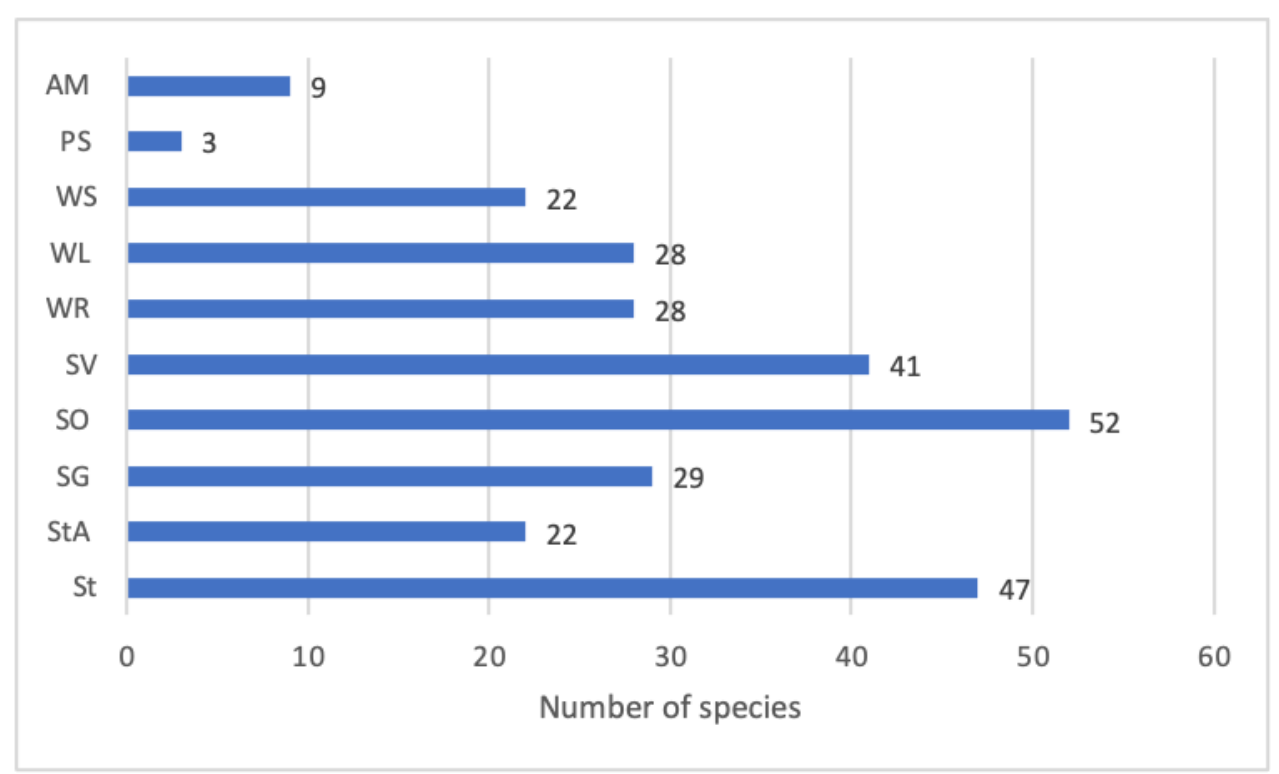

Fig. 3: The number of bryophyte species on different types of substrate in the Znesinnya RLP 


\section{Discussion}

The territory of Znesinnya RLP covers both natural landscapes with a wide variety of natural conditions and contrasting relief in different areas, and technogenically modified landscapes (Dynamo ski slope, old Znesinnya cemetery, railway track and bridge). Green areas partially differ from indigenous coenoses in species composition, since invasive species, such as Acer negundo L., Robinia psudoacacia L., Quercus rubra L. and Aesculus hippocastanum L., are widespread in the tree layer. It should be noted that these tree species, as with species growing in natural coenoses (e.g., Acer platanoides L., A. pseudoplatanus L., Betula pendula Roth., Quercus robur L., Carpinus betulus L., Sorbus aucuparia L., Tilia cordata Mill.), create favourable conditions for the growth of epiphytic bryophytes, which are found in the basal and root zones, and often in the middle zone of tree trunks. A similar species composition of epiphytes is typical for forest parks in urban ecosystems [7, 9, 11, 13, 26].

On tree trunks (epiphytic group, WL), urbanophilic and urban-neutral species typical for city parks are distributed (Orthotrichum sp., Leskea polycarpa, Pseudoleskeella nervosa, Hypnum cupressiforme, Pylaisia polyantha, Brachytheciastrum velutinum, Sciuro-hypnum populeum, Platygyrium repens) [30-31], as well as species typical for forests with a lower anthropogenic pressure (Radula complanata, Isothecium alopecuroides and Homalia trichomanoides), which indicates stable local conditions for the growth of urbanophobic epiphytes on phorophytes. In the basal zone of old trees, abundant moss growths are widespread with the participation of Plagiomnium cuspidatum, P. rostratum, Brachythecium rutabulum, Atrichum undulatum, Plagiothecium curvifolium, P. cavifolium, etc.

The most common are toxico-tolerant epiphytic mosses, which are eurybionts in urban ecosystems. These are species such as Platygyrium repens, Pylaisia polyantha, Hypnum cupressiforme and Leskea polycarpa. The presence of the monitoring species Homalia trichomanoides [23-25] indicates possible favourable conditions for colonizing urbanophobic species in the territory of Znesinnya RLP.

Distribution in the basal zone of trees and on protruding roots of a significant number of facultative epiphytic species of bryophytes, which are also found on other substrates (stones and rotten wood) in the Znesinnya RLP, is due to favourable conditions, primarily moisture created by other vegetation and the presence of a soil layer. Bryologists drew attention to such favourable microclimatic conditions for facultative epiphytes, and also to the fact that species such as Ceratodon purpureus, Brachythecium sp., Hypnum cupressiforme, Amblystegium serpens, Barbula unguiculata and Tortula muralis can withstand exhaust pollution, the presence of salt, petroleum and other environmental pollutants [33, 36].

Bare soil patches in the Znesinnya RLP are found on and along paths, on road slopes, eroded steep slopes, etc. Fresh outcrops are usually occupied by pioneer species of moss, such as Ceratodon purpureus, Barbula unguiculata, Bryum argenteum, B. klinggraeffii, Ptychostomum imbricatulum, which form multi-species turfs. Liverworts such as Marchantia polymorpha, Blasia pusilla and Pellia sp. are common on a wet loam substrate in ravines and near streams. The mosses Aloina rigida, Didymodon rigidulus, D. vinealis, Encalypta streptocarpa occur on gravelly screes of the steep slopes of former quarries, while Weissia brachycarpa, W. longifolia, Brachythecium albicans, B. campestre, B. glareosum, Rhynchostegium murale and Pleuridium subulatum are 
found on rocky slopes with meadow-steppe vegetation.

A group of forest and meadow species of bryophytes that prefer soils with a layer of leaf litter or colonize herbaceous vegetation (SV) can be specified separately. In particular, in wooded areas, the bryophyte cover is represented by sylvatic species of mosses such as Atrichum undulatum, Fissidens taxifolius, F. dubius, Dicranella heteromalla, Plagiomnium undulatum. Areas with herbaceous vegetation (meadows, forest edges, hayfields, and lawns) are inhabited by Abietinella abietina, Brachythecium campestre, B. glareosum, B. salebrosum, Calliergonella cuspidata, Climacium dendroides, Drepanocladus aduncus, Oxyrrhynchium hians, Rhytidiadelphus squarrosus, Thuidium assimile.

Stony substrates, both natural (St), such as limestone and sandstone, and artificial (StA) (e.g., concrete, cement, brick, stone stairs, pavement, cobblestones, stone statues and benches) are habitats for lithophilic species (Bryum argenteum, Bryoerythrophyllum recurvirostrum, Grimmia pulvinata, Schistidium apocarpum, S. crassipilum, Syntrichia ruralis, Rhynchostegium murale, Tortella tortuosa, Tortula muralis), and for bryophytes of a wider substrate range (Brachytheciastrum velutinum, Brachythecium salebrosum, Ceratodon purpureus, Drepanocladus aduncus, Hygroamblystegium varium, Hypnum cupressiforme, Leskea polycarpa, Plagiomnium rostratum, and Pohlia nutans). In general, a number of bryological studies indicate the expansion of the possibilities of bryophytes colonizing artificial substrates in urban ecosystems [1, 8, 12, 27].

On natural dead wood, stumps and logs, ecologically plastic species of bryophytes of the epixilic group (WR) are mainly distributed, such as Hypnum cupressiforme, Brachytheciastrum velutinum and Brachythecium rutabulum. Due to the specifics of management in the Znesinnya RLP, there are no fallen branches, stumps and fallen trunks present; however, a small number of epixilic species have been recorded, which is generally characteristic [12, 14-15, 30-31]. On the other hand, wooden landscape design elements (stairs, gazebos, etc.) are common in the park; in addition, on the territory of the Skansen there are numerous wooden buildings on which species of bryophytes (Orthotrichum pumilum, Lewinskya speciosa, Dicranum montanum) can colonize, but the dominant species are Hypnum cupressiforme and the cosmopolitan Ceratodon purpureus. An interesting anthropogenic substrate for mosses is the roofs of houses on the territory of the Scansen. In particular, abundant growths of the non-specifically epixilic mosses Brachythecium rutabulum, Brachytheciastrum velutinum and Hypnum cupressiforme were observed on rotten straw.

The group of mosses confined to the water bodies of the Znesinnya RLP is small in number and includes only 13 species. Four of them are confined to habitats along the banks of water bodies and swampy plots (PS), which have been preserved in some places at the bottom of old quarries. The species Warnstorfia fluitans, Leptodictyum riparium, Drepanocladus aduncus, Amblystegium serpens are found there. Amphibious bryophytes (AM) are peculiar species distributed on substrates that are permanently or temporarily submerged in water. The characteristic habitat of these species is tufa formations in the upper reaches of the Glybokiy stream, which lies in a wooded ravine. Moss species such as Conocephalum conicum, Pellia endiviifolia, P. epiphylla, Palustriella commutata, Cratoneuron filicinum and Brachythecium rivulare are distributed there.

On the territory of Znesinnya RLP, six regionally rare species of bryophytes were found: Pellia endiviifolia, P. epiphylla, Encalypta streptocarpa, Fissidens exilis, Cirriphyllum crassinervium, and Sciurohypnum starkei. The distribution of Pellia endiviifolia and P. epiphylla is confined to a specific habitat, the hard water springs with active formation of tufa or travertine 
(the so-called petrifying springs with tufa formation), found on the territory of Lviv Skansen [21]. This biotope is included in the list of especially valuable habitats of the nature protection network NATURA-2000 [20]. The mosses Encalypta streptocarpa, Cirriphyllum crassinervium, Sciurohypnum starkei are tied to outcrops of dense carbonate rocks in the canyons of former quarries in the park. The first species is confined to lightened habitats, while the other two are confined to shaded boulders with a layer of organic matter. The moss Fissidens exilis was found on Mount Khomets, among the grass cover of a meadow-steppe area, where many plant species included in the Red Data Book of Ukraine have been found [22].

Significant species diversity of bryophytes in the Znesinnya RLP, in contrast to parks in other cities $[12,16,40]$, can be explained primarily by its territory with a diverse microrelief creating favorable micro-habitats [32], as well as by its nature conservation status [8].

The presence of bryophytes, their species composition and substrate affiliation, as well as the study of their ecological features in specific ecotopes are important for assessing changes in the environment [14].

\section{Conclusions}

Znesinnya Regional Landscape Park, located in the city of Lviv, includes a wide variety of both natural and anthropogenically disturbed ecotopes that are the habitat of bryophytes. The results of this study demonstrate a high diversity of bryoflora inhabiting the Znesinnya RLP. A total of 113 species of bryophytes have been recorded, of which 105 species are representatives of the division Bryophyta, and 8 species belong to the division Marchantiophyta. The inventory of bryoflora species found in the Znesinnya RLP includes representatives of 66 genera, 35 families and two divisions, with six species of bryophytes being regionally rare. Most of the bryophytes occurring in the study area are epigeous $(89.0 \%$ of the total number of species), while $42.5 \%$ of the species are epiliths that colonize stony substrates. The bryoflora of Znesinnya RLP contains in equal proportions epiphytic and epixilic species $(24.8 \%$ each) and the smallest part $(10.7 \%)$ of species inhabiting aquatic and boggy ecotopes. In general, the territory of Znesinnya RLP is characterized by the process of synanthropization of flora, including bryophyte species. Negative processes are especially pronounced in areas exposed to significant recreational stress. In particular, the destruction of the grass cover, with xerophytization of ecotopes, leads to the spread of cosmopolitan species or to the disappearance of hygrophilic and mesophytic species.

\section{REFERENCES}

1. Andriyeva O. \& Ragulina M., 2009, Flora of the walls of the Lviv city. Natural anthology: series of biological sciences. Kherson: PP Vyshemyrskyy, 12: 6-18.

2. Bachuryna H.F \& Melnychuk V.M., 1987, Moss Flora of the Ukrainian SSR. Vol. 1. Naukova Dumka, Kyiv.

3. Bachuryna H.F \& Melnychuk V.M., 1988, Moss Flora of the Ukrainian SSR. Vol. 2. Naukova Dumka, Kyiv.

4. Bachuryna H.F \& Melnychuk V.M., 1989, Moss Flora of the Ukrainian SSR. Vol. 3. Naukova Dumka, Kyiv.

5. Bachuryna H.F \& Melnychuk V.M., 2003, Moss Flora of the Ukraine. Vol. 4. Naukova Dumka, Kyiv.

6. Boiko M.F., 2010, Rare bryophytes from plane and mountain landscapes of Ukraine. Chornomorski Botanical Journal 5: 294-315.

7. Fintha G., Szilárd C. \& Szücs P. 2021, The Bryophyte Flora of the Szent István University Gödöllö Botanical Garden. Acta Biologica Plantarum Agriensis 9 (1): 3-15. DOI: 10.21406/abpa.2021.9.1.3 
8. Fojcik B., 2011, Mchy Wyżyny Krakowsko-Częstochowskiej w obliczu antropogenicznych przemian szaty roślinnej. Wydawnictwo Uniwersytetu Ślaskiego. Wydawnictwo Uniwersytetu Ślaskiego Katowice.

9. Fojcik B., \& Stebel A., 2014, The diversity of moss flora of Katowice town (S Poland). Cryptogamie, Bryologie 35 (4): 373-385. DOI: 10.7872/cryb.v35.iss4.2014.373

10. Frahm J.P. \& Frey W., 2004, Moosflora. Ulmer. Stuttgart

11. Fudali E. \& Żołnierz L., 2019, Epiphytic bryophytes in urban forests in Wrocław (SW Poland). Biodiversity: Research and Conservation 53: 73-83. DOI: 10.2478/biorc-2019-0005

12. Godovičová K., 2019, Protected area "Horský park" as a bryorefugy in urban environment of Bratislava. Acta Botanica 54: 31-37.

13. Goia I. \& Danci O., 2006, Epyphytic bryophytes as bioindicators of air quality in Baia Mare city (Romania), Environment \& Progress, 6: 204-209.

14. Goia I. \& Moraru I., 2014, Contributions to the bryophyte flora of the "Valea Morii" nature reserve. Studia Universitatis Babes-Bolyai, Biologia, 59 (2): 31-38

15. Goia, I., \& Gafta, D., 2019, Beech versus spruce deadwood as forest microhabitat: does it make any difference to bryophytes? Plant Biosystems-An International Journal Dealing with all Aspects of Plant Biology, 153 (2): 187-194. DOI: 10.1080/11263504.2018.1448011

16. Gospodinov G., Lambevska-Hristova A., Natcheva R \& Gyosheva M., 2018, Vrana Park-a neglected site for bryophyte and fungal diversity in Sofia city. Phytologia Balcanica 24 (3): 323-329.

17. Hodgetts N. G., Söderström L., Blockeel T. L., Caspari S., Ignatov M. S., Konstantinova N. A., Lockhart N., Papp B., Schröck C., Sim-Sim M., Bell D., Bell N. E., Blom H.H., Bruggeman-Nannenga M. A., Brugués M., Enroth J., Flatberg K. I., Garilleti R., Hedenäs L., Holyoak D. T., Hugonnot V., Kariyawasam I., Köckinger H., Kučera J., Lara F \& Porley R. D., 2020, An annotated checklist of bryophytes of Europe, Macaronesia and Cyprus, Journal of Bryology, 42 (1): 1-116. DOI: 10.1080/03736687.2019.1694329

18. Ignatov M.S \& Ignatova E.A, 2003, Moss flora of the Middle European Russia. KMK Press, Moscow.

19. Ignatov M.S \& Ignatova E.A., 2004, Moss flora of the Middle European Russia. KMK Press, Moscow.

20. Kagalo A. \& Prots B., 2012, Habitat concept of biodiversity protection: basic documents of the European Union. ZUKC, Lviv.

21. Kagalo A., Omelchuk O., Orlov O., Ragulina M. \& Sytschak N., 2020, The habitat diversity and its sosological evaluation of the Lviv museum of folk architecture as an example of previous analysis of anthropogenic landscape demutations, Proceedings of the State Natural History Museum. Lviv 36: 107-114. DOI: $10.36885 / \mathrm{nzdpm} .2020 .36 .107-114$

22. Lysenko H., Danylyk I. \& Borsukevych L., 2010, Comparative synphytoindication assessment of Podillya meadow steppes. Visnyk of L'viv Universit - Biological Series. 53: 9-18.

23. Mamchur Z.I. \& Prots B.H., 1996, Behaviour of macrophytobiota in urbanization circumstances (as exemplified by Lviv town). Ukrainian Botanical Journal 53 (5): 611-614.

24. Mamchur Z.I., 1998, Epiphytic bryophytes of the Lviv Town and environs Ukrainian Botanical Journal 55 (3): 279-286.

25. Mamchur Z., 2005.Bryoindication of air pollution of Lviv city and surroundings. Visnyk of L'viv University - Biological Series 40: 59-67.

26. Mamchur Z. \& Bilska I., 2013, Epiphytic bryophytes features in urban environment Visnyk of L'viv University 61: 125-132.

27. Mamchur Z.I., \& Chuba M.V., 2016, The ecological features of synanthropic flora of dense housing area of Lviv, Studia Biologica 10 (1): 143-154. DOI: https://doi.org/10.30970/sbi.1001.466

28. Mamchur Z.I., Chuba M.V., \& Drach Yu.A., 2017, Mosses and vascular plants on railway tracks in the Lviv city, Visnyk of L'viv University - Biological Series 75: 54-65.

29. Mamchur Z.I., Chuba M.V. \& Drach Yu.A., 2017, The ecological features of plants of railway in the Lviv city, Studia Biologica 11 (1): 135-146. DOI: https://doi.org/10.30970/sbi.1101.519

30. Mamchur Z.I., Drach Yu.A. \& Danylkiv I.S., 2018. Bryoflora of the "Pohulyanka" forest park (Lviv city). Changes in taxonomic composition under antropogenic transformation, Studia Biologica 12(1): 99-112. DOI: $10.30970 /$ sbi.1201.542

31. Mamchur Z., Drach Yu. \& Antonyak H., 2020, Ecological features and synanthropization of bryoflora in the Pohulyanka forest park (Lviv city, Ukraine), Contribuţii Botanice 55: 83-95. DOI: 10.24193/Contrib.Bot.55.5 
32. Natcheva R. \& Gospodinov G., 2020, The bryophyte flora of Loven Park in the city of Sofia, Bulgaria, Phytologia Balcanica 26 (3): 445-447.

33. Plášek V., Nowak A., Nobis M., Kusza G. \& Kochanowska K., 2014, Effect of 30 years of road traffic abandonment on epiphytic moss diversity. Environmental monitoring and assessment 186 (12): 8943-8959.

34. Pokorny L., Lara F. \& Mazimpaka V., 2006, The bryophyte flora of the city of Trento (North Italy). Cryptogamie, Bryologie 27 (2): 1-20.

35. Polishchuk A.I. \& Antonyak H.L., 2019, Accumulation of heavy metals in gametophytes of the epilithic mosses. Studia Biologica; 13 (2): 21-28. DOI: https://doi.org/10.30970/sbi.1302.601

36. Polishchuk A.I., Antonyak H.L. \& Pershyn O.I., 2019, Accumulation of metals in gametophytes of some species of mosses in the city of Lviv (Ukraine), Bulletin of Problems in Biology and Medicine 3 (152): 5862. DOI: 10.29254/2077-4214-2019-3-152-58-62

37. Sabovljevic M. \& Grdovic S., 2009, Bryophyte diversity within urban areas: case study of the city of Belgrade (Serbia). International Journal of Botany 5: 85-92.

38. Sabovljević M. \& Sabovljević A., 2009, Biodiversity within urban areas: A case study on bryophytes of the city of Cologne (NRW, Germany), Plant Biosystems 143 (3): 473-481. DOI: 10.1080/11263500903178075

39. Scherbachenko O. \& Rabyk I., 2004. Bryophytes of the side zone of Lviv reservoirs, Proceedings of the State Museum of Natural History 19: 39-46.

40. Szücs P., Fintha G. \& Fazekas G., 2020, The bryophyte diversity of Central Park (Archbishop's Garden) of Eger town (Hungary). Acta Biologica Plantarum Agriensis 8 (1): 3-16. DOI: 10.21406/abpa.2020.8.1.3

41. Vukojević V., Sabovljević M., Sabovljević A., Mihajlović N., Dražić G. \& Vučinić Ž., 2009, Determination of heavy metal deposition in the County of Obrenovac (Serbia) using mosses as bioindicators. IV. Manganese (Mn), molybdenum (Mo), and nickel (Ni). Archives of Biological Sciences 61 (4): 835-845. DOI: $10.2298 / \mathrm{ABS} 0904835 \mathrm{~V}$

42. Zerov D.K., 1964, Flora of hepatic and sphagnum moss of Ukraine. Naukova Dumka. Kiev.

\section{GRUPURILE DE BRIOFITE ÎN FUNCT⿱IE DE SUBSTRAT DIN PARCUL REGIONAL ZNESINNYA (LVIV, UCRAINA)}

\section{(Rezumat)}

Articolul prezintă informații asupra diversității și grupurilor în funcție de substrat ale brioflorei din Parcul Regional Znesinnya (Znesinnya RLP), localizat în orașul Lviv (vestul Ucrainei). Pe baza studiilor din teren în perioada 2015-2018 și a analizei colecților de herbar a fost realizat un inventar al brioflorei din Znesinnya RLP. În aria investigată, s-au înregistrat un număr de 113 specii de briofite aparținând la 66 genuri, 35 familii și 2 diviziuni. Dintre acestea, 105 specii aparțin diviziunii Bryophyta, iar 8 aparțin la Marchantiophyta. Au fost determinate 6 specii regionale rare, și anume: Pellia endiviifolia, P. epiphylla, Encalypta streptocarpa, Fissidens exilis, Cirriphyllum crassinervium și Sciurohypnum starkei. În ceea ce privește preferința față de substrat, au predominat speciile epigee $-89.0 \%$ din numărul total de specii. Cea mai mare parte a briofitelor apar pe sol (46\%), în timp ce $36.3 \%$ și $25.7 \%$ au fost găsite pe sol în vegetația ierboasă, respectiv pe sol cu pietriș. Substraturile pietroase au fost colonizate de către $42.5 \%$ dintre speciile de briofite, cu $19.5 \%$ dintre specii care apar pe substraturi pietroase artificiale. În plus, $24.8 \%$ dintre specii aparțin epixilelor, ce apar pe trunchiuri vechi de copaci cu grade diferite de putrefacție, iar în aceeași proporție au fost prezente speciile epifite. Cea mai mică proporție (10.7\%) au reprezentat-o briofitele acvatice și din ecotopurile mlăștinoase. 